\section{ECONOMICS}

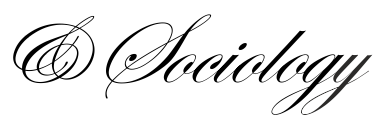

Wolf, I., Levi, S., \& Lopez del Rio, L.C. Y (2021). Moving toward funded pension scheme: Pure economic argument due to population aging or responsibility abdication of governments?. Economics and Sociology, 14(4), 151-166. doi:10.14254/2071-789X.2021/14-4/9

\title{
MOVING TOWARD FUNDED PENSION SCHEME: PURE ECONOMIC ARGUMENT DUE TO POPULATION AGING OR RESPONSIBILITY ABDICATION OF GOVERNMENTS?
}

\author{
Ishay Wolf \\ Ono Academic College \\ Tel-Aviv, Israel \\ E-mail:ishay.wo@,ono.ac.il \\ ORCID 0000-0003-1513-2391 \\ Smadar Levi \\ Ono Academic College \\ Tel-Aviv, Israel \\ E-mail:_evi.smadar4@gmail.com \\ Lorena Caridad Y Lopez del \\ Rio \\ Cordoba University \\ Cordoba, Spain \\ E-mail:d92calol@uco.es
}

Received: March, 2021

1st Revision: November, 2021

Accepted: December, 2021

DOI: $10.14254 / 2071-$

789X.2021/14-4/9

JEL Classification: D02, O17, P31

\begin{abstract}
This study adopts a unique angle towards exploring pension plans in a modern western market influenced by aging. In particular, much weight has been attributed to the effects of the Covid-19 pandemic crisis and frequent market turmoil. The full set of players involved in the pension system has been considered with its different interests among both the current and future generations In addition, we factor in the difference among earning cohorts. By using the overlapping generations model and Monte Carlo simulations, we note that in a wide macroeconomic range, pension equilibrium among the market's players lies with the unfunded pension scheme despite the significant influence of aging. Contrary to the classic economic arguments presented by the World Bank and IMF, ideas that were widespread during the 1980s and 1990 s, the choosing of pension system is much more complex. Public administrations must take into account not only the aging rhythm and market expected yields but also other parameters, such as the current and future utility perspective, the government's debt price, GDP per capita growth rate, risk aversion, and the possibility of market turmoil.
\end{abstract}

\footnotetext{
Keywords: pension system, minimum pension guarantee, risk sharing, social security.
}

\section{Introduction}

The western world deals with continuous aging, low fertility, and debt crisis that push governments introduce funded-capitalised pension schemes (Clements et al. 2018; Holzmann \& Hinz, 2005; Feldstein, 2005). A common trend is for public pension benefits to decline (OECD, 2020). Moreover, systemic reforms have altered the nature of pension provisions, consequently shifting more risks onto the pension earners. The privatisation of pension plans worldwide and the global inclination towards the adoption of more funded plans raise 
important questions regarding the optimal pension scheme, its benefits, and pitfalls (Barr \& Diamond, 2009; Ebbinghaus, 2019).

The sharp downturn in the value of financial assets between 2007 and 2009 and the current financial crisis due to the COVID-19 pandemic serve as accurate examples of how risky assets quickly lose a significant part of their value (Milev, 2021). The financial crises and continuing concerns about retirement security have generated a new policy interest in the role the country plays in providing adequate old-age benefits to its citizens. We are now witnessing a great wave of pension withdrawals from funded-capitalized schemes towards embracing more governmental intervention. Most countries that had been experiencing the economic downturns were the first to implement the new liberal pension schemes during the 1990s (Ebbinghaus, 2019; Altiparmakov, 2018; Grech, 2018).

Contributing to the adequate pension strand in the current unstable pension landscape, this research suggests that from wide perspective, the rush move of governments towards funded pension schemes, due to low fertility and fiscal constraints, may not be optimal. The notion of setting up individual account is not new, but it expanded with the World Bank's support during the 1990s. The shrinking tax base and the negative influence of governments on markets are the flag of the Washington Consensus, the World Bank during the 1990s, and other economic institutes (Heneghan \& Orensein, 2019). In conjunction with the current fiscal expenditures lies once again the classic economic argument that countries should shift to funded pension schemes due to low fertility (Gruber \& Wise, 1999).

Recent research has demonstrated the importance of balancing funded schemes with unfunded components to increase adequacy and sustainability (Wolf \& Ocerin, 2021; Wolf \& Caridad, 2021a; Dornam, 2006). The current research reinforces the expanding policy of governments economic intervention around the world as part of their effort to boost the economy after the pandemic shocks and simultaneously insure old participants against the turmoil markets (Wolf \& Caridad, 2021c; Feher \& De Bidegain, 2020). We base this plea on simple equilibriums in the pension markets based on different macro-economic assumptions.

The novelty of this research is in the extensive array of interests it takes into consideration. We avoid treating participants as one single player, distributing its interest across four different generations, where each generation includes high and low earning cohorts. The adjacent generations allow us to examine the cyclical tax burden, fertility's influence on future generations, and the statistical returns in the long term. The classification to earning cohorts demonstrates the different interests of hedging capabilities, various optimal contribution rates, considering tax burden and insurance components in old age benefits.

We recommend balancing funded pension schemes with 'unfunded boxes', which may increase the sustainability of the pension system, and thus the utility of all players. It has been observed that in some cases, common in western economies, the optimal pension scheme is surprisingly the Pay-As-You-Go defined benefit pension system, even in aging societies.

The next section details the interests of the different players in the pension field as well as the assumptions over the economic model. In section 3, we proposed the stochastic model of the pension system, maximising the participants' utility, analysing how it is best to finance the guarantee. Section 4 presents the main results of the simulations and sensitivity analysis. In section 5, we discuss the results and their implications, while the last section provides the conclusion.

\section{The government and the participants interests}

It is common to determine that the government wish to decrease its fiscal risks and obligations and hence push to shift to unfunded pension scheme. The fiscal exposure of the government is obviously levied in its citizens (Clements et al., 2018). Consequently, it should 
be the interests on the citizens to shift from the comfort PAYG DB pension scheme to funded pension design. Indeed, some scholars mainly during the 1990s support the transition to funded scheme trying to convince that the alternative is a heavy tax burden (Feldstein, 1991; Holzmann \& Hinz, 2005).

Disassembling to society to different players the answer to this question seems to be much more complex and far from unambiguous. Since information is not a free asset but a risk in pension systems, framing the argument in second-best terms starts from the multiple objectives of pension systems. "Policy has to seek the best balance between consumption smoothing, poverty relief, and insurance, and this balance will depend in each society on the weights given to those and other objectives and to the different constraints that societies face." (Barr \& Diamond, 2010).

This composition focus on the central planner, which has the responsibility to balance the interests of all players - recognizing variety of earning cohorts and adjacent generations. That variety of actors throughout its length and breadth may represents the entire government perspective. By that, we continue Altiparmakov (2018) and Wolf and Ocerin (2021), who suggest that stable pension system must seek for an equilibrium between earning cohorts. Otherwise, the chances are high for pension reforms and reversals (Ortiz et al. 2018; Naczyk \& Domonkos, 2016).

We expand previous OLG models (Wolf \& Caridad, 2021; Cipriani, 2019) by including debt. The consideration of cycle government debt, obligate the central planner to make sure future generations will not be used as a heavy tax source. Here in this research we take future generations' utility as part of the total preferences of the society by simple discounting them. One may claim that the weight for future generations in preferences equations is not necessary derives from the participant's discount factor and may suggest higher weight. We agree to that argument and claim that still the equilibrium in that case should be calculated specifically to every market separately.

The second dimension is the differentiation between high and low earning cohorts. Wolf and Caridad (2021) have shown that by shifting to funded pension scheme socio economic anomaly exists because of the high exposure of low earning cohorts to market and credit risk without the ability to hedge themselves. They also claim that the optimal contributions rates are generally close to high earning preferences (see also Wolf and Ocerin, 2021). In that case the funded pension market should be included an 'Externalities', where high earners compensate low earners by risk sharing. That may include for example minimum pension guarantee, intergenerational / intra-generational risk sharing of social security benefits. These processes clearly justify differentiating considerations and interests of earning cohorts.

\section{Model Set-Up}

We employ a simple overlapping generations (OLG) model to characterize optimal pension pillars sizes. In each period, a new generation of unity mass is borne. We employ this model for four generations. For simplicity, each generation includes three equal life periods cycle frameworks as in Knell (2010). Individuals work during the first two parts of their life while they are retired during the third part. The first pillar is unfunded social security and the second is in the form of individual accounts. 


\subsection{Consumers}

We consider an economy populated by consumers who start working at the age of 21 $(s=0)$. The individual works over two period of 23 years each and retires at the age of 67 $\left(s=T_{R}\right)$. They live another third period for 23 years and die at the age of $90\left(s=T_{D}\right)$.

During the first 46 years, consumers work and earn a real labor income of $W_{t}{ }^{1} \cdot \mathrm{We}$ allow for differentiation in wage levels across earning deciles. From this wage, the individual contributes social security tax and contributes to funded pension fund. the participant consume the residual after contributions.

During the retirement period $\left(T_{R} \leq s<T_{D}\right)$, the individual does not work anymore, and his consumption, $C_{t, T_{R}}$, is given by the benefits both from public PAYG social security and revenues from his private defined-contribution fund; these benefits are collectively denoted by $P_{t}$. The consumption of generation $t$ in time $s$ can be described as:

$$
c_{t, s}=\left\{\begin{array}{cl}
W_{t, s}(1-\tau), & \text { during work period } \\
p_{T_{R}}^{U}+p_{T_{R}}^{F}, & \text { during retirement }
\end{array}\right\}
$$

Individuals have constant relative risk aversion (CRRA2) utility function defined over a single nondurable consumption good. Let us define $\delta$ as the discount factor, $\alpha$ measures the curvature of the utility function or risk aversion level, and the individual's preferences are then defined by:

$$
U_{t}=\sum_{s=1}^{s=2} \delta^{s-1} \frac{1}{1-a}\left(c_{t, t+s-1}\right)^{1-a}+\delta^{2} \frac{1}{1-a}\left(c_{t, T_{R}}-m p g_{t, T_{R}}\right)^{1-a}
$$

Here, $C_{t, s}$ is the consumption level of generation $t$ in periods. $m p g_{t, s}$ is the level of government guarantee for generation $t$ in period $s$. Generally, the guarantee can dress many forms, such as relative rate benefit or constant benefit. This model attributes to the general case of old age target income. In other words, the guarantee benefits if the individual's total old age benefits summed to less than a specified social threshold. Here this threshold is defined at the poverty line ( $60 \%$ of median income).

Consumption is a function of the participant's wage and deductions due pension contributions (funded and unfunded) and taxes financing government debt. Government's debt can made due to financing pension guarantee or financing intergenerational gaps in PAYG DB due to aging. These payments are detailed in Table 1 below. In fact, the aging effect comes to realize in twofold positions. First, by increasing the real debt cost of the government, as less people participate in a specified burden. Second, by reducing PAYG benefits per specified contribution rate.

Consistently with the life cycle model of Modigliani (1966), the participant aware of future interest rates risk and adapt his consumption during working phase accordingly. If the government supposed to collect extra tax payments to finance the interests of its debts, the individual adapts his consumption accordingly.

\footnotetext{
${ }^{1}$ All variables throughout this paper are expressed in real terms. It is assumed that wage inflation is identical to price inflation.

${ }^{2}$ In the literature it is common to use the coefficient of relative risk aversion $R R A \equiv \frac{U^{\prime \prime}(c)}{U^{\prime}(c)} * c$ for the utility function of the form.
} 
Table 1. Consumption in each pension scheme

\begin{tabular}{lccc}
\hline Consumption & Defined Benefit & Mix Pension Scheme & $\begin{array}{c}\text { Mix pension scheme with } \\
\text { pension Guarantee }\end{array}$ \\
\hline $\begin{array}{l}\text { During } \\
\text { working phase }\end{array}$ & $\begin{array}{c}\text { Wage - pension } \\
\text { contributions- tax } \\
\text { financing aging effect (the } \\
\text { cost of shrinking tax base) }\end{array}$ & $\begin{array}{c}\text { Wage - pension } \\
\text { contributions }\end{array}$ & $\begin{array}{c}\text { Wage - pension } \\
\text { contributions- tax financing } \\
\text { guarantee cost of earlier } \\
\text { generations }\end{array}$ \\
\hline $\begin{array}{l}\text { During } \\
\text { Retirement }\end{array}$ & $\begin{array}{c}\text { Unfunded pillar with no } \\
\text { aging effect }\end{array}$ & $\begin{array}{c}\text { Funded + unfunded } \\
\text { pillar }\end{array}$ & $\begin{array}{c}\text { Funded + unfunded pillar + } \\
\text { minimum pension guarantee } \\
\text { until the poverty line }\end{array}$ \\
\hline
\end{tabular}

\subsection{Mix pension scheme with dominant funded pillar}

Rates of returns are uncertain (ex-ante expected utility). GDP per capita growth rate approximates the aggregate wage income, following the same method of Masten and Thorgesen (2004), Wolf and Ocerin (2021). We also assume that the real PAYG rate of return, $g_{s+1}$, is equal to the growth rate of wages or the change in the GDP per capita.

The parameter $g_{t}$ describes the evolution of the wage, $W$, which follows a Brownian motion in the form:

$$
\frac{d W(t)}{W(t)}=d g_{t}=\mu_{g} d t+\sigma_{g} d B^{W}(t)
$$

Where $\mu_{g}$ stands for the constant expectation of the instantaneous variation rate in the wage, $\sigma_{g}$ its constant standard deviation, and $B^{W}$ is a standard Brownian motion. The first phrase is a constant drift and second phrase is the volatility drift, respectively. Term $g_{t+1}$ is the growth of labor income or the return on human capital.

The individual pays a fixed contribution rate $\tau$. From that contribution, a share of $\gamma$ is being invested in a private funded pillar and a share of $(1-\gamma)$ finances the unfunded pillar or the public social security. The pension benefit for generation $t$ in the retirement period is denoted by:

$$
p_{T_{R}}=p_{T_{R}}^{F}+p_{T_{R}}^{U}
$$

Here, $p_{t+2}^{F}, p_{t+2}^{U}$ represents the funded fund and social security (PAYG), respectively. We allow correlation between GDP per capita and the fund asset return rate, thus:

$$
d B^{W}(t) d B^{A}(t)=\rho_{w, A} d t
$$

With the condition $1 \geq \rho_{w, A} \geq-1$.

We assumed a constant social security benefit base on time of contributions. In each period, the working population's contributions are equal to total benefit payments to retirees. Consequently, the public un-funded pension benefit is determined by the balance budget condition of:

$$
\varphi \tau^{U}\left\{\bar{W}_{t+1, T_{R}} N_{t+1} * A+\bar{W}_{t+2, T_{R}} N_{t+2} * A^{2}\right\}=\sum_{n=1}^{N_{T_{R}}} p_{t}^{U}
$$

Here, $\tau^{U}$ is the contribution rate to social security, $N_{t}$ is the size of the generation born in period $t$, and $p_{t}^{U}$ is the unfunded pension benefits paid to generation $t$ in the period of $T_{R}$. 
Term $\varphi$ is the constant social security's old-age benefits/contribution ratio. The residual share $(1-\varphi)$ of contributions finance other social expenses such as Medicare, means-tested, minimum pension guarantee, disability benefits, unemployment benefits, and other social expenses. The tax base in each generation is shrinking due to aging of societies. Consequently, $A$ represents the aging factor of each contributor generation to social security.

Under the assumption of a constant population growth, $n i_{t}$, the contribution $\tau^{U} w_{t, s}$ paid by generation $\mathrm{t}$ in time $s$; thus, there is a return of $g_{s+1}=\left(W_{t, s+1} / W_{t, s}\right)-1$. In addition, we assume the economic principle of Aaron (1966) that the notional interest rate or the population growth rate is set equal to the growth rate of wages: $n i_{t}=g_{t}$. Hence, the unfunded benefit at retirement can be described in the reduced form of:

$$
P_{t, T_{R}}^{U}=\varphi(1-\gamma) \tau \sum_{t=1}^{T} \partial_{d} \bar{W}_{t+1, T_{R}} *\left(A+A^{2}\right)
$$

Where $\partial_{d}$ is a constant parameter per earning decile that adjust the benefit to contribution level. This mechanism is similar to the Notional Defined Contribution (NDC) pension scheme and enables higher benefits to high earners in relate to their contributions.

The funded-capitalized pillar is a private collective defined-contribution (DC) system with a fixed contribution rate. Individuals start with zero initial asset holdings. The individual adds the fraction of $\gamma w_{t}$ to his accumulations during the working phase, which is invested in a constant portfolio mix of financial assets (equities, bonds, etc.). This accumulation earns an average annual rate of return of: $r_{t}$. This rate of return also follows a Brownian motion in form of:

$$
d r_{s}=\mu_{r} d t+\sigma_{r} B^{A} d t
$$

Here, $r_{t}$ denotes the continuous rate expectation of the asset instantaneous return rate, $\sigma_{r}$ its constant standard deviation, and $B^{A}$ standard Brownian motion. The first phrase from the left is a constant drift and second phrase is the volatility drift.

The funded pillar is equal to the accumulated capital from the contributions to the private collective defined-contribution fund in every working period until retirement $\left(T_{R}\right)$. The real capital is given by:

$$
p_{t}^{F}=\left(1-T^{f}\right)\left(1-I^{f}\right) \tau^{F} \sum_{s=t}^{T_{R}} W_{t, s} r_{t}^{T_{R}-t}
$$

Here, $T^{f}$ is the effective tax rate on old-age funded fund's benefits. $I^{f}$ is the fraction from contributions represents insurances contributed from the pension fund, such as disability. Funded fund's liabilities are based on current and future retiree's benefit payments. The funded benefit can be described more specifically as:

$$
p_{t}^{F}=\gamma \tau W_{t} r_{s+1} r_{s+2}+\gamma \tau W_{t+1} r_{s+2}
$$

Due to the assumption that there is only one period of retirement, it is not necessary to specify how the pension capital of the funded pillar is annuitized or amortized, i.e. transformed into annual pension installments. 


\subsection{Pension guarantee}

The government considers implementing minimum pension guarantee, when imposing the funded pension scheme. The periodical guarantee is at the poverty level, meaning 0.6 of the median earning decile. We calculate the cost of the guarantee as:

$$
\text { Guarante Cost at time } t=p \text {. l at time } t-\left(p_{t}^{F}+p_{t}^{U}\right)
$$

The poverty line itself is growing every period by the GDP per capita growth rate. However, the guarantee cost depends on the income inequality in the market and stays constant as a percentage from GDP. The guarantee cost is finance by the government in the form of tax levied on future generations.

\subsection{PAYG DB pension scheme}

Pension benefits are calculated at the same method of the unfunded pillar above. The difference is that total contribution are for unfunded pillar $(\gamma=0)$. In addition, the retirees benefit from constant contribution level. The government through debt finances the exposure of aging, which reduce the intra-generational financing base.

$$
P_{t, T_{R}}^{D B}=\varphi \tau \sum_{t=1}^{T} \partial_{d} \bar{W}_{t+1} * 2
$$

As the government keep benefit retirees at the same original level before transition, the shrinking tax base is translated to a fiscal expenditure. That expenditure is financed by future generations as tax payments in the amount of:

$$
P_{t, T_{R}}^{D B} \text { government share }=\varphi \tau \sum_{t=1}^{T} \partial_{d} \bar{W}_{t+1} *\left(2-\left(A+A^{2}\right)\right)
$$

\subsection{Government debt}

Government finance two different obligations through debt and future tax. The first is the guarantee cost in mix funded pension scheme. The second is the aging influence of the intra-generational tax base from generation to generation.

In each of these expenses, we assume a debt cycle of four periods. In the first period, fiscal expense is realized. Over the next two periods, the working population pays the interestrate component as a tax, while during the fourth period, return also the principle in addition to the periodically interest payment. In total, in each period, working generation pays three interest rate components of past debts and a single principle of past debt.

\subsection{Different Earning Cohorts}

We allow different preferences among earning cohorts. In fact, this diversity is one of the most important novelty of this research. We assume that high earning cohorts benefit from higher share of GDP growth than low earners, in increasing order. In parallel, high earners levy higher share of tax payments, progressively. For example, the tax burden on decile 4 is only $5 \%$ from payment, while $30 \%$ on the highest earning decile. Figure 1 summarizes the differentiating across different earning deciles. 
We value the preferences of earning cohorts to different pension scheme by the change of average utility computed according to each of the three pension schemes analyzed. For simplicity, we group these preferences by deciles 1-4 for low earning cohorts and 7-10 for high earning cohorts.

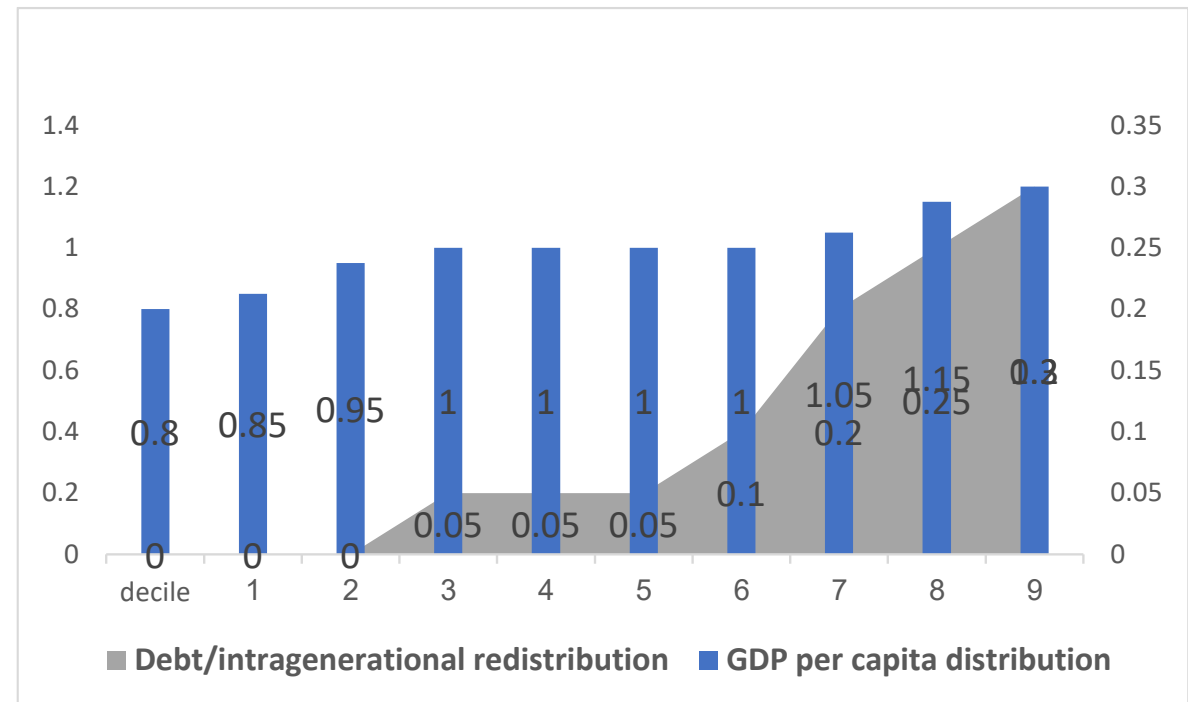

Figure 1. Earning deciles

Source: own calculation

\section{Simulation and calibration}

The GDP per capita stochastic yields turns to be stochastic the variables of periodic wage, poverty line, defined benefit pension scheme and social security. The market yield affects stochastically the funded pension pillar. We use Monte Carlo simulations to simulate the level of the guarantee cost in each generation and the level of governmental debt due to imposing defined benefit in each generation. Another set of Monte Carlo simulation is conducted to compute the preferences of each earning cohort on each generation among funded pension scheme, funded scheme with guarantee and defined benefit pension scheme.

For each generation, the preference of pension scheme depends by the utility of each earning cohort in each generation. For comparability, we compute the relative preference of the mix pension scheme over the DB and respectively the preference of the mix pension scheme with guarantee over the DB. Monte Carlo simulations simulate these pairs of ratios.

Analyzing the results, we differentiate between low and high earning cohorts. For each set of results we discount the preferences of the four generations to a single number.

We calibrate the model as of average Western OECD country, using its updating data base (OECD, 2020). In the base scenario, the government capital cost is $0.5 \%$, the GDP per capita is $1.6 \%$ a year and the average net pension market yield is $3.74 \%$. contribution rates to pension pillars derived from countries which runs dominant funded pension scheme such as Denmark and Israel (OECD, 2020). We take into considerations the aging trend in Western countries. We assume high aging influence to keep conservative in analyzing the rush toward funded scheme. In that case, similar to Germany and Spain, dependency ratio increases in $0.4 \%$ every year. Sensitive analysis is conducted to map trends of preferences as function of risk aversion and interest rate gap. We summarize the calibrations variables in Table 2. 
Table 2. Calibration

\begin{tabular}{|l|c|}
\hline \multicolumn{2}{|c|}{ Wage and Pension Systems } \\
\hline Contribution rate & 0.3 \\
\hline Funded rate from contributions & 0.75 \\
\hline Annual Expected S.D. of funded pillar & $18 \%$ \\
\hline Gross return (OECD 2018) & $4.3 \%$ \\
\hline Admin. Cost & $0.5 \%$ \\
\hline Funded Benefit tax rate & $20 \%$ \\
\hline Annual Expected GDP per capita - g & $1.6 \%$ \\
\hline Annual GDP S.D & $2 \%$ \\
\hline Social Security Benefit / Contribution coeff. & $60 \%$ \\
\hline Insurances in funded pension funds from contribution & $25.00 \%$ \\
\hline \multicolumn{2}{|c|}{ Macro-Economic Parameters } \\
\hline Risk Aversion Coeff. (Base Scenario) & 3 \\
\hline Annual Intesrt rate (Base Scenario) & $0.10 \%$ \\
\hline Total population annual growth & $0.30 \%$ \\
\hline Dependency ratio annual change & $0.4 \%$ \\
\hline Annual discount factor & $\mathrm{G}+1.3 \%$ \\
\hline
\end{tabular}

\section{Results and insights}

While there is no debt financing in the funded pension scheme, the DB pension scheme involves small debt financing (the aging effect) We map the higher debt level financing the guarantee, reducing in time, if GDP per Capita $>r_{f}$.

In the common Western market, the government interest rate is lower than the GDP per capita rate, while the market yield $(r)$ is higher than both of them. When the difference between the market yield and the GDP per capita increases, markets prefer to shift to funded pension schemes and vice versa. Here, we regard the government capital price as also an important factor since it affects the preferences of future generations. A coherent pension system, which considers multiple-players' preferences, cannot avoid the tax/PAYG burden levied on the working population or future generations in the form of tax payments cycle.

\subsection{PAYG-DB scheme vs. funded pension scheme}

For each generation, we check the preferences between PAYG-DB and funded pension scheme via 2100 Monte Carlo simulations. Each simulation calculates the OLG model with the abovementioned assumptions. Figure 2 mentions these preferences based on earning cohorts and as function of rate of returns gaps (GDP per capita minus the government interest rate). The more positive the preference value, the more the preference tends to the funded scheme. In the same vein, the more negative the value, the more the utility function tend to prefer the PAYG DB pension scheme. 
INTERDISCIPLINARY APPROACH TO ECONOMICS AND SOCIOLOGY

\begin{tabular}{|c|c|c|c|c|c|c|}
\hline \multicolumn{7}{|c|}{ Panel A: Low Earning Deciles } \\
\hline \multicolumn{2}{|c|}{$\begin{array}{l}\text { Interest rate gap / } \\
\text { Generation } \\
\text { Preference }\end{array}$} & A & B & C & D & $\begin{array}{c}\text { Preference to } \\
\text { end of } \\
\text { genertion A }\end{array}$ \\
\hline \multirow{8}{*}{ g-r } & $1.50 \%$ & $-2.21 \%$ & $-1.31 \%$ & $-0.73 \%$ & $-0.39 \%$ & $-3.7 \%$ \\
\hline & $1.30 \%$ & $-2.03 \%$ & $-1.14 \%$ & $-0.64 \%$ & $-0.36 \%$ & $-3.2 \%$ \\
\hline & $1.10 \%$ & $-1.77 \%$ & $-1.05 \%$ & $-0.59 \%$ & $-0.31 \%$ & $-2.8 \%$ \\
\hline & $0.90 \%$ & $-1.54 \%$ & $-0.94 \%$ & $-0.51 \%$ & $-0.27 \%$ & $-2.4 \%$ \\
\hline & $0.70 \%$ & $-1.38 \%$ & $-0.80 \%$ & $-0.43 \%$ & $-0.22 \%$ & $-2.1 \%$ \\
\hline & $0.50 \%$ & $-1.26 \%$ & $-0.69 \%$ & $-0.37 \%$ & $-0.17 \%$ & $-1.8 \%$ \\
\hline & $0.30 \%$ & $-1.06 \%$ & $-0.58 \%$ & $-0.28 \%$ & $-0.12 \%$ & $-1.5 \%$ \\
\hline & $0.00 \%$ & $-0.74 \%$ & $-0.37 \%$ & $-0.15 \%$ & $-0.03 \%$ & $-1.0 \%$ \\
\hline
\end{tabular}

\begin{tabular}{|c|c|c|c|c|c|c|}
\hline \multicolumn{7}{|c|}{ Panel B: High Earning Deciles } \\
\hline \multicolumn{2}{|c|}{$\begin{array}{l}\text { Interest rate gap / } \\
\text { Generation } \\
\text { Preference }\end{array}$} & A & B & C & D & $\begin{array}{c}\text { Preference to } \\
\text { end of } \\
\text { genertion A }\end{array}$ \\
\hline \multirow{8}{*}{ g-r } & $1.50 \%$ & $-3.34 \%$ & $-2.74 \%$ & $-3.82 \%$ & $-2.91 \%$ & $-8.5 \%$ \\
\hline & $1.30 \%$ & $-0.32 \%$ & $0.35 \%$ & $-0.01 \%$ & $1.59 \%$ & $0.4 \%$ \\
\hline & $1.10 \%$ & $3.23 \%$ & $2.67 \%$ & $1.93 \%$ & $4.43 \%$ & $7.1 \%$ \\
\hline & $0.90 \%$ & $5.00 \%$ & $5.74 \%$ & $8.03 \%$ & $8.84 \%$ & $14.0 \%$ \\
\hline & $0.70 \%$ & $8.88 \%$ & $9.22 \%$ & $10.96 \%$ & $12.91 \%$ & $21.5 \%$ \\
\hline & $0.50 \%$ & $12.59 \%$ & $13.76 \%$ & $15.70 \%$ & $17.89 \%$ & $29.3 \%$ \\
\hline & $0.30 \%$ & $16.14 \%$ & $18.00 \%$ & $19.92 \%$ & $22.19 \%$ & $35.8 \%$ \\
\hline & $0.00 \%$ & $22.37 \%$ & $24.91 \%$ & $26.66 \%$ & $29.82 \%$ & $46.7 \%$ \\
\hline
\end{tabular}

Figure 2. Generations' preferences of PAYG-DB vs. funded scheme in the base scenario $(a=$ 3)

\section{Source: own calculation}

As expected, high earners prefer the funded pension scheme, while low earners are inclined towards the DB scheme. For high earners, the reasons behind their preference are the potential for higher benefits and disinclination towards financing pension gaps of unfunded transfers due to aging and shrinking labor force.

Low-earning cohorts prefer the DB pension system as it provides insurance although in average the benefits in the funded scheme are higher. With time, in both types of cohorts, the attractiveness of the funded scheme increases as, on average, its returns are higher than the GDP per capita, and naturally, the insurance for the long term is less considered in the utility measure.

When raising the risk aversion coefficient from 3 to 5 , low earners become almost indifferent between the funded and unfunded pension schemes. This is because, in high-risk aversion measures, participants place heavy weight on their current consumption more than their old-age benefits. Since consumption does not change, the total utility change is almost constant.

According to Figure 3, among high earners, the preference for unfunded pension schemes is dramatic. That tendency is moderated with generations, and naturally when government debt cost increases. In other words, even when the tax burden due to aging is levied on high earners and thus consumption and their old-age benefits are lower than in the funded pension scheme, they will much rather prefer unfunded pension schemes most of the returns gap array. Additionally, when risk aversion increases, high earners' preferences for the PAYG-DB pension system increase than the mix pension scheme with pension guarantee. We explain that by the high insurance embedded in the first option and lower tax burden. Because 
of the frightened in the markets. that conclusion is highly important mainly during market turmoil.

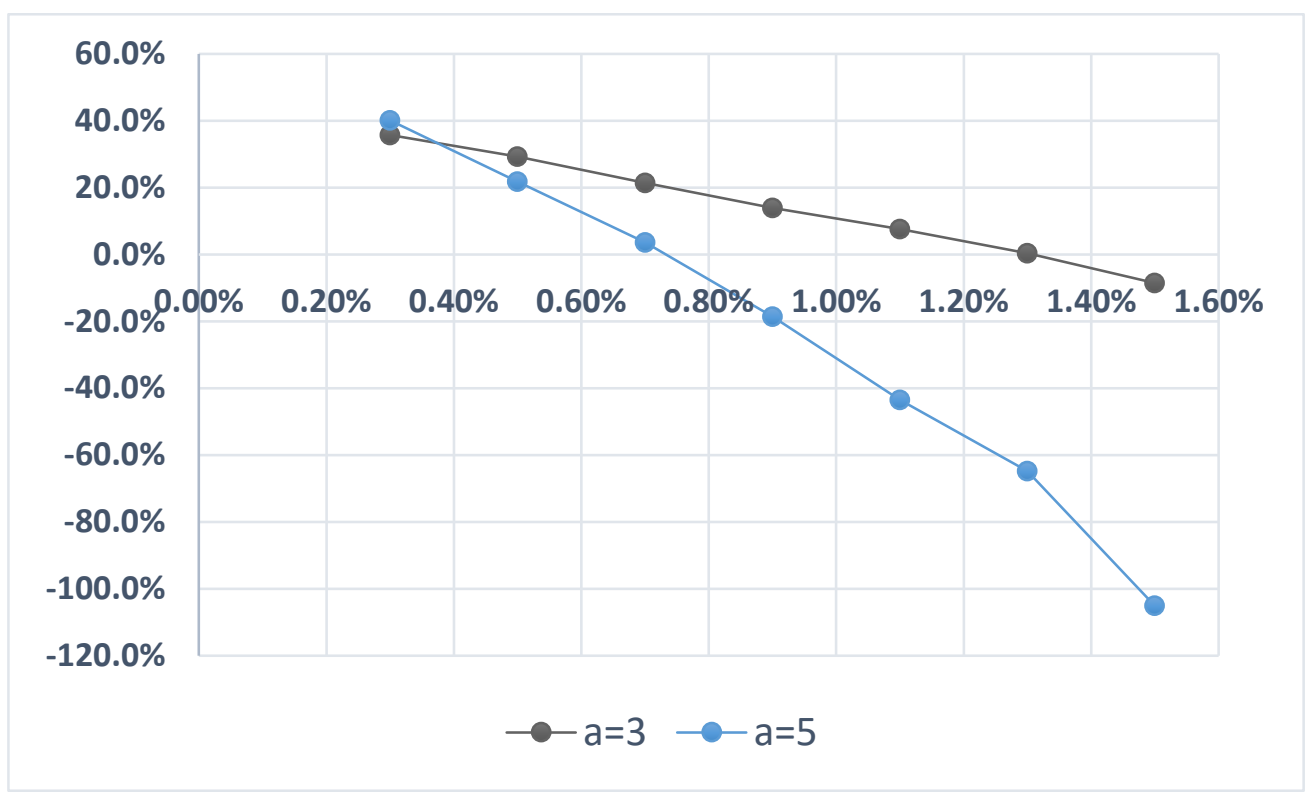

Figure 3. High earners' preference when risk aversion increase Source: own calculation

\subsection{PAYG-DB scheme vs. mix pension scheme with pension guarantee}

Figure 4 compares along the base scenario the preferences between the PAYG-DB scheme and the mix pension scheme with pension guarantee. According to the results, there is not much difference between the two possibilities to the low earners (the blue line). The benefit level is quite similar; in both cases, there is an insurance component, and in both cases, the tax burden does not fall on this earning cohort. As the gap between the GDP per capita and government's interest rate decreases, the discounting factor diminishes, and the attractiveness of the PAYG-DB scheme decreases. It is most interesting to understand the results for high earners, who finance the insurance components in both pension systems. It is significant to determine that high earners would prefer the PAYG-DB pension scheme over the alternative. The reason is mostly the high financing cost of the guarantee. Figure 4 illustrates that when the government's interest rate increases (small gap), the preference for PAYG-DB increases accordingly, avoiding a higher tax burden.

As we allow differentiation in decile wealth growth, income inequality increases with time. The poverty line is indexed to the GDP per capita while high-earning deciles' wealth grows faster. That makes the guarantee price relatively lower along generations, which comes to realize by decreasing percent from the total GDP.

In general, if the GDP per capita is higher than government interest rate, clearly, the central planner would prefer to accumulate debt and roll it over the years as the principal and interest rate payment decrease as a percent from the GDP. Along generations, the preferences for the DB pension scheme tend to decrease as the average return effect increases. However, for high earners, the attractiveness between the two pension schemes is not ambiguous. High earners prefer the DB pension scheme because of lower tax burden during the working phase. In other words, they would rather choose old-age benefits than to pay the relative high tax burden due to the guarantee. 


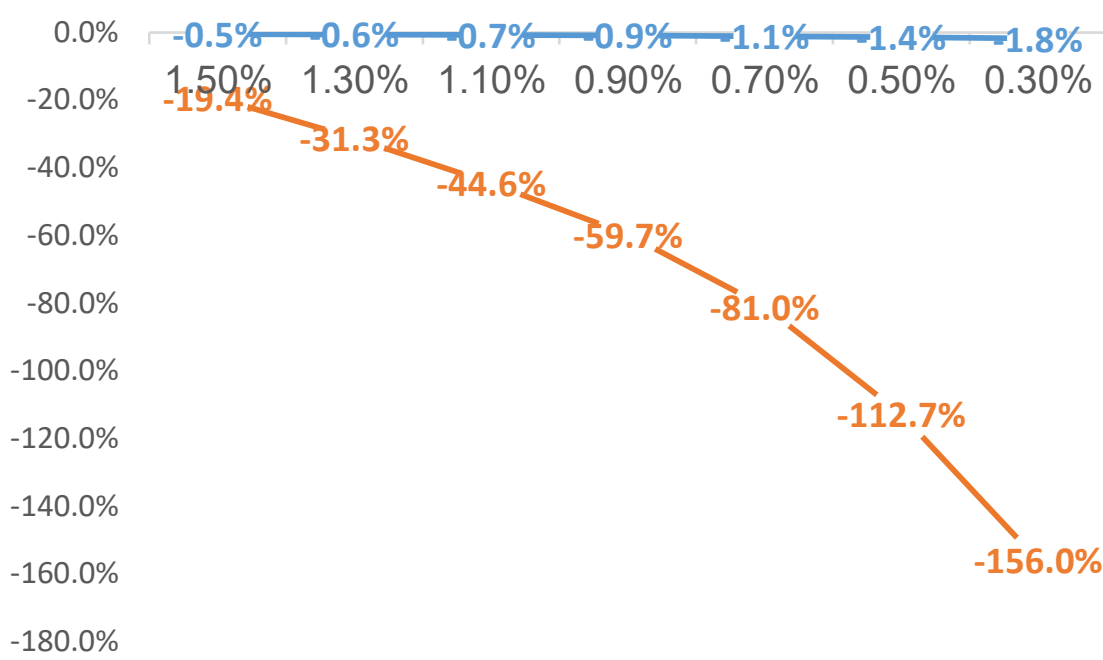

- -low earners - -high earners

Figure 4. The preference between the PAYG-DB and mix pension system Source: own calculation

\subsection{Finding an equilibrium point}

Equilibrium in pension systems is not just a matter of economy but also involves social targets (Barientos, 2019). Even when poverty alleviation is highly weighted among the central planners' considerations, it is not straightforward decision to implement mix pension system with minimum guarantee. Although low earners only slightly prefer the unfunded scheme over the mix scheme with the guarantee, high earners strongly prefer the unfunded scheme and avoid financing the high costs of the guarantee. Consequently, considering these two options, in the wider perspective of all players, the system should adopt the PAYG-DB pension system.

That conclusion is certainly relevant in an aging society with clear economic characteristics of Western countries. In other words, the potential old-age benefits for high benefits in the funded pension scheme is offset by the taxes burden to fund social targets.

In this research, we show that the PAYG-DB scheme provides a common equilibrium even when releasing the assumption of social targets. One can see that in Figure 2, where the gap between the GDP per capita and the government debt cost is large (1.5-1.3\%), the players would prefer the PAYG-DB scheme. That simple equilibrium is relevant also when risk aversion increases or the yield's standard deviation increases. Naturally, in these situations, participants prefer safer benefits even if it means lower consumption during the working phase. That conclusion is most relevant when markets are not stable, for example, due to the COVID-19 pandemic crisis.

More complex scenarios can be identified when the gap between the GDP per capita and the government debt price is narrow. For example, as shown in Figure 2, when the gap is at $1.1 \%$, low earners prefer the unfunded pension scheme (measure of "-2.8\%"). In parallel, high earners prefer the funded scheme (measure of "7.1\%") while resisting the mix scheme (measure of "-44.6\%" in Figure 4). The non-preference of neither of the players types toward the mix pension system suggested the exclusion of that option from the realistic equilibrium variety.

Between the unfunded and the funded pension scheme, we seek a point satisfying the players' interests that in turn increases the chances to ensure system sustainability. With given 
macroeconomic parameters, we seek a new mix pension system, which includes an 'unfunded box', shifted from high earners to low earners, at retirement. That shift compensates low earners' exposure to excess market risk and low abilities to hedge it. From another economic angel, high earners finance this compensation due to the characteristics of contribution rates being close to the optimal for high earners and sub-optimal for low earners (Wolf \& Caridad, 2021). In fact, this shift creates equilibrium according to the 'Externalities' theory and alleviates the inherent socio-economic anomaly in funded pension schemes, which favors high earners.

\begin{tabular}{|l|c|c|c|c|c|c|}
\hline \multicolumn{7}{|c|}{ Panel A } \\
\hline $\begin{array}{c}\text { Earning } \\
\text { cohort }\end{array}$ & $\begin{array}{c}\text { Box size } \\
\text { (\%GDP) }\end{array}$ & A & B & C & D & $\begin{array}{c}\text { Preference to end } \\
\text { of genertion A }\end{array}$ \\
\hline \multicolumn{7}{|c|}{ The Base Scenario } \\
\hline low & $3.30 \%$ & $-1.77 \%$ & $-1.05 \%$ & $-0.59 \%$ & $-0.31 \%$ & $\mathbf{- 2 . 8} \%$ \\
\hline high & $3.30 \%$ & $2.80 \%$ & $3.00 \%$ & $3.63 \%$ & $4.34 \%$ & $\mathbf{7 . 6 \%}$ \\
\hline \multicolumn{7}{|c|}{ Finding Equilibirium Point } \\
\hline high & $\mathbf{3} \%$ & $-7.63 \%$ & $-8.82 \%$ & $-8.45 \%$ & $-9.00 \%$ & $\mathbf{- 1 9 . 7 \%}$ \\
\hline high & $\mathbf{2} \%$ & $-4.35 \%$ & $-4.66 \%$ & $-3.84 \%$ & $-4.24 \%$ & $\mathbf{- 1 0 . 3 \%}$ \\
\hline \multicolumn{1}{|c|}{ high } & $\mathbf{1} \%$ & $\mathbf{- 1 . 2 4} \%$ & $\mathbf{- 1 . 3 9} \%$ & $\mathbf{0 . 2 7} \%$ & $\mathbf{0 . 6 6} \%$ & $\mathbf{- 1 . 9} \%$ \\
\hline
\end{tabular}

\begin{tabular}{|c|c|c|c|c|c|c|}
\hline \multicolumn{7}{|c|}{$\begin{array}{c}\text { Panel B } \\
\text { GDP per capita - government interst rate }=0.9 \%\end{array}$} \\
\hline $\begin{array}{r}\text { Earning } \\
\text { cohort }\end{array}$ & $\begin{array}{r}\text { Box size } \\
\text { (\%GDP) }\end{array}$ & A & B & C & D & $\begin{array}{l}\text { Preference to end } \\
\text { of genertion } A\end{array}$ \\
\hline \multicolumn{7}{|c|}{ The Base Scenario } \\
\hline low & $3.60 \%$ & $-1.77 \%$ & $-1.05 \%$ & $-0.59 \%$ & $-0.31 \%$ & $-2.7 \%$ \\
\hline high & $3.60 \%$ & $2.80 \%$ & $3.00 \%$ & $3.63 \%$ & $4.34 \%$ & $7.2 \%$ \\
\hline \multicolumn{7}{|c|}{ Finding Equilibirium Point } \\
\hline high & $2 \%$ & $-1.71 \%$ & $-1.59 \%$ & $-1.02 \%$ & $-0.71 \%$ & $-3.3 \%$ \\
\hline high & $1 \%$ & $3.08 \%$ & $2.48 \%$ & $3.61 \%$ & $4.81 \%$ & $7.3 \%$ \\
\hline
\end{tabular}

\begin{tabular}{|c|c|c|c|c|c|c|}
\hline \multicolumn{7}{|c|}{$\begin{array}{c}\text { Panel C } \\
\text { GDP per capita - government interst rate }=0.7 \%\end{array}$} \\
\hline $\begin{array}{r}\text { Earning } \\
\text { cohort }\end{array}$ & $\begin{array}{r}\text { Box size } \\
\text { (\%GDP) }\end{array}$ & A & B & C & D & $\begin{array}{c}\text { Preference to end } \\
\text { of genertion } A\end{array}$ \\
\hline \multicolumn{7}{|c|}{ The Base Scenario } \\
\hline low & & $-1.38 \%$ & $-0.80 \%$ & $-0.43 \%$ & $-0.22 \%$ & $-2.1 \%$ \\
\hline high & & $8.88 \%$ & $9.22 \%$ & $10.96 \%$ & $12.91 \%$ & $21.5 \%$ \\
\hline \multicolumn{7}{|c|}{ Finding Equilibirium Point } \\
\hline high & $3 \%$ & $-0.37 \%$ & $-1.06 \%$ & $-0.23 \%$ & $-0.65 \%$ & $-1.2 \%$ \\
\hline high & $2 \%$ & $3.02 \%$ & $2.84 \%$ & $3.10 \%$ & $3.96 \%$ & $6.8 \%$ \\
\hline high & $1 \%$ & $6.89 \%$ & $5.93 \%$ & $7.27 \%$ & $8.93 \%$ & $15.2 \%$ \\
\hline
\end{tabular}

Figure 5. Finding an equilibrium point in the funded pension scheme Source: own calculation

Finding the unfunded 'box' size, we analyze the preferences while low earners benefit from it and high earners finance it. Figure 5 plots the convergence process towards equilibriums based on the funded scheme plus the unfunded box. We learn that even in the case of a small amount of shifting (low box size), high earners would prefer to stay in the DB- 
PAYG scheme. That is valid even for debt levels that are far lower than the PAYG-DB base scenario. For example, in Panel A, when the returns gap is $1.1 \%$, high earners would prefer the PAYG-DB scheme even with a minimum level of box (1\% of GDP). In Panel B, when the gap is shorter, the equilibrium will be at the funded scheme with the unfunded box of $2 \%$ GDP. In these two cases, one can determine that the equilibrium is extremely fragile, meaning it is actually the PAYG-DB scheme. In panel $\mathrm{C}$, when the returns gap is at $0.7 \%$, the suggested equilibrium is at the funded scheme with the unfunded box of 3\% GDP. From that gap level and lower levels, the model suggests of the equilibrium involving the funded pension scheme.

\section{Discussion}

The influence of aging is perceived as an intergenerational burden (Bohn, 2011), which increases over the years. That idea was incorporated in the base arguments made by the World Bank for convincing economies to shift to funded pension systems during the 1990s (Noy, 2018). The motivation to converge to an equilibrium is first of the government itself, avoiding fiscal expenses on reverting and ensuring political support from all players (Guardiancich \& Guidi, 2020).

The fiscal concerns due to the aging process is indeed intuitive; however, it might push governments to introduce funded pension schemes too fast. According to the findings, the insurance effect of the unfunded pension scheme is beneficial even at the cost of shrinking tax base. A low interest rate environment and sufficient gap between the GDP per capita and the government's interest rate mostly suggest keeping unfunded pension schemes. In markets with a narrowed gap, equilibriums can be set with the funded pension scheme with some unfunded box strengthening low earners pensions at retirement. Notably, the equilibrium with the funded scheme is quite fragile, where a slight change in the macroeconomic variables will cause even high earners to prefer the unfunded pension scheme. In addition, the preference for the unfunded scheme is strengthened in times of market instability.

In addition to the results, supporting a mix pension design along with a risk-sharing mechanism, we count another fiscal motive of the government to avoid the extensive funded scheme, surprising as it may be sound. Altiparmakov (2018) shows that CEE countries revert to the unfunded pension scheme to control all sort of contributions and tax of its citizens. In other words, during financial crisis, governments wish to raise chip money, and unfunded contribution is a fast way to do that.

\section{Conclusion}

The key feature of this research is the consideration of multiple players in the field, as the pension system affects across generations and earning cohorts. By treating the society as one single entity managing financial risks, we may lose the opportunities to pursue other interests and avoid potential equilibriums in the markets. Seeking stable pension markets is one of the top priorities of central planners, especially in a period of uncertainty in other markets due to the pandemic and the global debt crisis.

While the preferences of low earners clearly gravitate towards the unfunded pension scheme, it is most interesting to examine high earners' preferences. Here, we consider the assumptions of mutual risk-sharing among earning cohorts, solving the inherent socioeconomic anomaly in the funded scheme, which favors high earners at the expense of low earners (Wolf \& Caridad, 2021). 
The findings point that central planners must not rush towards funded pension funds although the society is aging. The move towards funded pension schemes in aging markets must not be a way out for governments from considering multiple players' game and to avoid other macro-economic parameters, such as debt level, debt price, and GDP per capita factors. Here, we mention the global trend of shifting to funded schemes even in non-aging markets, such as in Israel (Lurie, 2018). We find, in this research, that the unfunded pension scheme should be considered as most efficient to all actors in a wide variety of macroeconomic conditions, especially when the interest rates are very low, as they are in this period.

In times of the pandemic, central planners have to minimise the possibilities of unstable pension markets and reversals. That period for itself increases the motive to find a sustainable equilibrium in the market. In addition, governments must reconsider the frightened in the markets in these times. In our model, that realised by means of higher standard deviation of the market yield and higher risk aversion. Both realisations imply higher chances for an equilibrium in the unfunded pension scheme. These results are valid despite the aging of societies.

\section{References}

Aaron, H. (1966). The social insurance paradox. Canadian Journal of Economics and Political Science, 32(3), 371-374, https://doi.org/10.2307/139995.

Altiparmakov, N. (2018). Another look at causes and consequences of pension privatization reform reversals in Eastern Europe. Journal of European Social Policy, 28(3), 224-241. https://doi.org/10.1177/0958928717735053.

Ando, A., \& Modigliani, F. (1963). The "life cycle" hypothesis of saving: Aggregate implications and tests. The American Economic Review, 53(1), 55-84. Retrieved February 23, 2021, from http://www.jstor.org/stable/1817129

Barr N., \& Diamond, P. (2009), Reforming pensions: Principles, analytical errors and policy directions. International Social Security Review, 62(2), 5-29. https://doi.org/10.1111/j.1468-246X.2009.01327.x

Barrientos, A. (2009). Social protection in Latin America. in Welfare and social protection in contemporary Latin America, 2, Routledge.

Bohn, H. (2011). Should public retirement plans be fully funded? Journal of Pension Economics and Finance, 10(2), 195-219. http://doi.org/10.1017/S1474747211000096

Cipriani, G., \& Fioroni, T. (2021). Social security and endogenous demographic change: Child support and retirement policies. Journal of Pension Economics and Finance, 119. doi:10.1017/S1474747220000402

Clements, B., Dybczak, K., Gaspar, V., et al. (2018). The fiscal consequences of shrinking and ageing populations. Ageing International, 43, 391-414, https://doi.org/10.1007/s12126-017-9306-6

Dornan, P. (2006). Delivering benefits in old age: The take up of the minimum income guarantee (1st ed.). Routledge. https://doi.org/10.4324/9781351160162

Ebbinghaus, B. (2019). Multi-pillarisation remodelled: The role of interest organizations in British and German pension reforms. Journal of European Public Policy, 26(4), 521539, http://10.1080/13501763.2019.1574875.

Feldstein, M. (2005). Structural reform of social security. Journal of Economic Perspectives, 19(2), 33-55. http://doi.org.10.1257/0895330054048731

Gerard, F., Imbert, C., \& Orkin, K. (2020). Social protection response to the COVID-19 crisis: Options for developing countries. Oxford Review of Economic Policy, 36(1), 281-296, https://doi.org/10.1093/oxrep/graa026 
Grech, A. (2018). What makes pension reforms sustainable?. Sustainability, 10(8), https://doi.org/10.3390/su10082891

Gruber, J., \& Wise, D. A. (2008). Social security and retirement around the world. University of Chicago Press. https://doi.org/10.7208/9780226309996

Guardiancich, I., \& Guidi, M. (2020). The political economy of pension reforms in Europe under financial stress, Socio-Economic Review, mwaa012. https://doi.org/10.1093/ser/mwaa012

Heneghan, M., \& Orenstein, M. A. (2019) Organizing for impact: International organizations and global pension policy. Global Social Policy, 19(1-2), 65-86. doi:10.1177/1468018119834730

Holzmann, R., \& Hinz, R. (2005). Old-age income support in the 21st century: An international perspective on pension systems and reform. The World Bank. https://doi.org/10.1596/0-8213-6040-X

Knell, M. (2010). The optimal mix between funded and unfunded pension systems when people care about relative consumption. Economica, 77(308), 710-733. https://doi.org/10.1111/j.1468-0335.2009.00797.x

Lurie, L. (2018) Pension Privatization in Israel. In A. Paz-Fuchs, R. Mandelkern, I. Galnoor (Eds.) The privatization of Israel. Palgrave Macmillan, New York. https://doi.org/10.1057/978-1-137-58261-4_5

Masten, E., \& Thorgesen, O. (2004). Designing social security - A portfolio choice approach. European Economic Review, 48(4), 883-904. https://doi.org/10.1016/j.euroecorev.2003.09.006

Milev, J. (2021). The pandemic crisis and the resulted risks for the fully funded pension funds in Central and Eastern Europe. Research papers of UNWE, 2(1), 203-216,

Noy, S. (2018). Healthy targets? World Bank projects and targeted health programmes and policies in Costa Rica, Argentina, and Peru, 1980-2005, Oxford Development Studies, 46(2), 164-183. doi: 10.1080/13600818.2017.1346068

OECD (2019). Pension at Glance 2020: OECD and G20 Indicators. OECD Publishing. https://doi.org/10.1787/b6d3dcfc-en

Ortiz, I., Durán-Valverde, F., Urban, S., \& Wodsak, V. (2018). Reversing Pension Privatizations: Rebuilding public pension systems in Eastern Europe and Latin America. Geneva: International Labour Organization. https://doi.org/10.2139/ssrn.3275228.

Wolf, I. (2021). Political stress and the sustainability of funded pension schemes: Introduction of a financial theory. Journal of Risk and Financial Management, 14(11), 525. https://doi.org/10.3390/jrfm14110525

Wolf, I., \& Caridad Lopez del Rio, L., (2021c). Benefit adequacy in funded pension systems: Micro-simulation of the Israeli pension scheme. International Journal of Economics \& Business Administration, 9(2), 143-164. https://doi.10.10.35808/ijeba/694

Wolf, I., \& Caridad y Lopez del Rio, L. (2021a). Funded-capitalized pension designs and the demand for minimum pension guarantee. Public and Municipal Finance, 10(1), 12-24. https://doi.org/10.21511/pmf.10(1).2021.02

Wolf, I., \& Caridad y Lopez Del Rio, L. (2021b). Pension reforms and risk sharing cycle: A theory and global experience. International Journal of Economics \& Business Administration (IJEBA), 9(1), 225-242.

Wolf, I., \& Ocerin, J. M. C. (2021). The transition to a multi-pillar pension system: The inherent socio-economic anomaly. Journal of Financial Economic Policy. https://doi.org/10.1108/JFEP-07-2020-0162 